\title{
The transcription of Xenopus laevis embryonic U1 snRNA genes changes when oocytes mature into eggs
}

\author{
Elsebet Lund, Christopher J. Bostock, and James E. Dahlberg \\ Department of Physiological Chemistry, University of Wisconsin-Madison, Madison, Wisconsin 53706
}

\begin{abstract}
$X$. laevis stage VI oocytes respond differently from unfertilized eggs when injected with the genes for $X$. laevis embryonic U1 RNAs, xU1b1, and xU1b2. Upon maturation of oocytes into eggs, the efficiency of transcription decreases greatly and the ratio of $x U 1 b 1$ to $x U 1 b 2$ RNA transcription changes. Moreover, DNA replication is now required for transcription. Because of differences in the 5 '-flanking regions of the two xU1b genes, xU1b2 RNA transcription predominates after injection into oocytes; in contrast, xU1b1 RNA transcription predominates after injection into unfertilized eggs. Our results also indicate that in oocytes a factor that interacts with sequences close to the coding region is limiting, whereas in eggs a factor that recognizes farupstream sequences required for enhancer activity is limiting. Qualitatively, expression of the embryonic xU1b genes injected into eggs closely resembles that of the endogeneous genes during early embryogenesis.
\end{abstract}

[Key Words: Embryonic U1 RNA genes; snRNA transcription factors; X. laevis oocytes and unfertilized eggs; microinjection]

Received November 4, 1986; accepted November 26, 1986.

Xenopus laevis cells contain more than seven variant forms of U1 small nuclear RNA (U1 snRNAs) (Forbes et al. 1984) which are encoded by at least two different multigene families (Lund et al. 1984; Zeller et al. 1984). Following activation of transcription in early embryos at the midblastula transition (MBT) (Newport and Kirschner 1982b; Forbes et al. 1983a), the newly synthesized U1 RNAs are primarily the two so-called embryonic U1 RNAs, xU1b1 and xU1b2 (Forbes et al. 1984; Lund and Dalhberg, this issue). These RNAs (formerly called xUla and xU1b, respectively; Lund et al. 1984; Krol et al. 1985) are also the major species of U1 RNAs stockpiled during early oogenesis (Forbes et al. 1983b; Fritz et al. 1984; Lund and Dahlberg, this issue). As embryonic development proceeds, the synthesis of multiple species of adult U1 RNAs (the xUla RNAs, formerly called xUlc-g RNAs) predominates (Lund and Dahlberg, this issue).

The genes that code for the embryonic U1 RNAs are both present in at least 500 copies per haploid genome and comprise more than $90 \%$ of the $X$. laevis Ul genes. The $\mathrm{xU} 1 \mathrm{~b} 1$ and $\mathrm{xU} 1 \mathrm{~b} 2$ genes are paired in $1.8-\mathrm{kb}$ repeat units organized in large tandem arrays (Lund et al. 1984; Zeller et al. 1984). Upon injection into stage VI oocytes,

'Present address: The Animal Virus Research Institute, Pirbright, Woking, Surrey, England GU24 ONF, UK. cloned copies of the full-length repeat unit are transcribed efficiently to give mature xU1b RNAs (Ciliberto et al. 1985; Krol et al. 1985).

Although the $\mathrm{xU}$ lb gene repeats contain one copy each of the $x U 1 b 1$ and $x U 1 b 2$ genes, the synthesis of xU1b2 RNA predominates under standard conditions of DNA injection (Krol et al. 1985). This is in contrast to the normal in vivo situation in stage I and II oocytes and in embryos at the midblastula transition (MBT) when transcription of the endogenous $\mathrm{xUlbl}$ genes is either the same as, or more than, that of the endogenous $\mathrm{xU} 1 \mathrm{~b} 2$ genes (Forbes et al. 1984; Lund and Dahlberg, this issue).

We have examined the transcription of Ulb genes after injection into stage VI oocytes and unfertilized eggs, which represent developmental stages between the early oocyte and the MBT embryo. Stage VI oocytes are transcriptionally very active, but incapable of replicating DNA whereas activated but unfertilized eggs resemble early cleavage embryos in that they support high amounts of DNA replication, but low levels of RNA transcription (for review, see Gurdon and Melton 1981).

We show here that in both injected oocytes and injected eggs, the differential rate of transcription of one embryonic gene over the other is based on limiting levels of transcription factors. Moreover, different factors appear to be limiting in the two types of cells since the competition for them is mediated by different control regions upstream of the $x U 1 b 1$ and $x U 1 b 2$ 
Lund et al.

coding sequences. In eggs, but not in oocytes, the formation of active transcription complexes requires DNA replication.

\section{Results}

\section{Transcription in oocytes}

The two embryonic U1 RNA genes of $X$. laevis, $\mathrm{xU} 1 \mathrm{~b} 1$ and $x U 1 b 2$, differ by only two base pairs in the coding regions (Ciliberto et al. 1985; Krol et al. 1985), but the encoded RNAs can be readily distinguished by polyacrylamide gel electrophoresis (Forbes et al. 1984; Lund et al. 1984). However, the 5'-flanking regions of these genes differ significantly. To determine how these flanking sequences influence the relative transcription levels of the two genes, we constructed a variety of chimeric xUlb genes in which two sections of the 5 'flanking region were interchanged, as illustrated in Figure 1 . The region more proximal to the coding region includes the snRNA gene "TATA-box," i.e., sequences that are essential for correct transcription initiation of U1 RNA (Skuzeski et al. 1984; Ciliberto et al. 1985; Krol et al. 1985; Murphy et al. 1987); accordingly, we call this the proximal promoter region. The more distal sequences, upstream of about position -220 , contain the snRNA transcriptional enhancer; we call this the enhancer region. We note that both regions include considerably more sequence information than the TATA box or the enhancer.

When equal amounts of the genes for the two $\mathrm{xUlb}$ RNAs are injected separately into oocytes, using standard conditions (4-8 ng of DNA injected per oocyte), both genes are expressed equally well. However, when the genes are coinjected either on the same or separate plasmids, xU1b2 RNA accumulates at five- to tenfold the rate of xUlb1 RNA (Fig. 2; Krol et al. 1985). Neither the ratio of accumulated $x U 1 b 1$ to $x U 1 b 2$ RNAS /see Fig. 2A) nor the intracellular distribution of the two RNAs (i.e., nuclear versus cytoplasmic localization)

A

b1 b2

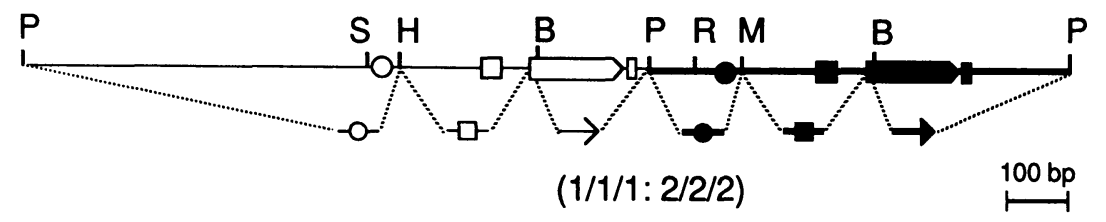

B
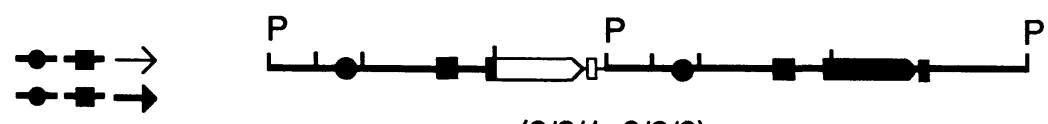

$(2 / 2 / 1: 2 / 2 / 2)$
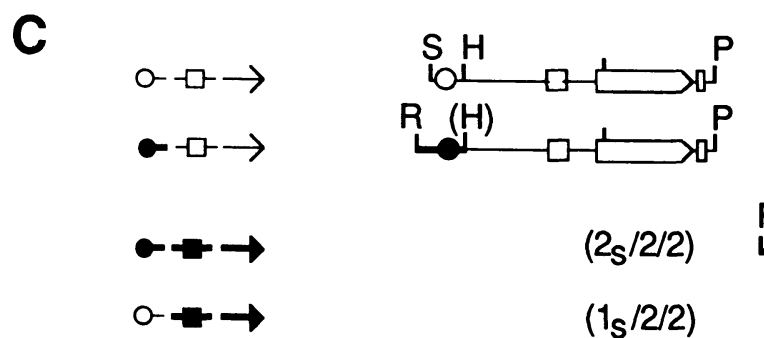

$(1 \mathrm{~s} / 1 / 1)$

$\left(2_{S} / 1 / 1\right)$

$(2 / 2 / 2)$

$(1 \mathrm{~s} / 2 / 2)$

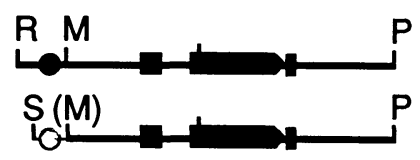

Figure 1. Structures of wild-type and chimeric $X$. laevis embryonic Ul genes. $(A)$ The standard wild-type $x U 1 b$ repeat unit containing one copy each of the $x U 1 b 1$ (b1) and $x U 1 b 2$ (b2) genes $(1 / 1 / 1: 2 / 2 / 2)$. The open and closed circles, boxes, and arrows indicate the positions of homologous regions between the two xUlb genes corresponding to the enhancer, the U1 TATA box, and the U1 coding sequences, respectively. The coding regions of the b1 and b2 genes differ at positions 78 and 114, downstream of the BclI sites at position +27 . The use of these symbols as cartoons of $x U 1 b$ genes (Fig. $1 B, C)$ is shown below the map. The positions of restriction enzyme cleavage sites used in constructions of chimeric templates are indicated. (P) PstI; $(\mathrm{S}) \operatorname{StuI} ;(\mathrm{H})$ HindIII; $(\mathrm{B})$ BclI; (R) RsaI; (M) MluI. (B) Example of a mutant xUlb repeat DNA. The Ul coding region and 5 -flanking region sequences of the bl and the b2 genes, respectively, were joined via the $B c$ II sites and this mutant b1 gene $(2 / 2 / 1)$ and the wild-type b2 gene $(2 / 2 / 2)$ were religated to generate the chimeric repeat $(2 / 2 / 1: 2 / 2 / 2)$ as described in Materials and methods. $(C)$ xU1b genes with truncated or chimeric $5^{\prime}$-flanking sequences. The truncated (short) bl and b2 genes, $\left(1_{s} / 1 / 1\right)$ and $\left(2_{s} / 2 / 2\right)$, contain 269 and $289 \mathrm{bp}$ of $5^{\prime}$-flanking sequences, respectively. The genes with the chimeric promoters, $\left(1_{s} / 2 / 2\right)$ and $\left(2_{s} / 1 / 1\right)$, contain the enhancer regions of the b1 gene (SH, positions -269 to $-222)$ and the b2 gene (RM, positions -289 to -219$)$, respectively. $(\mathrm{H})$ and $(\mathrm{M})$ indicate restriction enzyme cleavage sites that were converted to $\mathrm{XhoI}$ sites. 
A

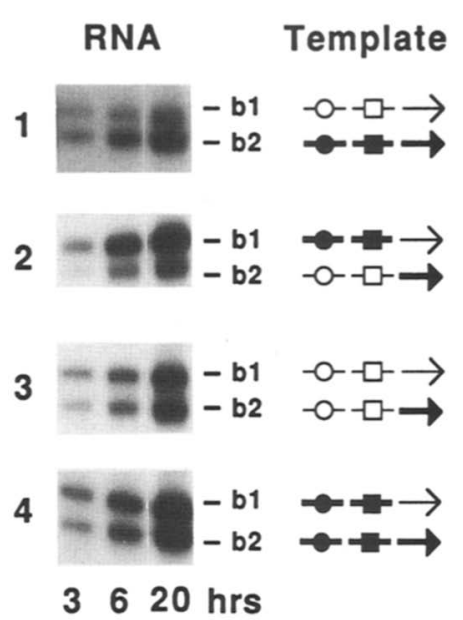

B

Figure 2. Transcription of $x U 1 b$ genes with wild-type and chimeric promoter regions in injected oocytes. $(A)$ Time course of $x U 1 b$ RNA synthesis in oocytes injected with wild-type (panel 1) or mutant (panels 2-4) xUlb repeat DNAs. As indicated by the cartoons (cf. Fig. 1), the mutant templates contained tandemly arranged xUlb genes with different (panel 2) or identical (panels 3 and 4 ) promoter regions. About 30-40 oocytes were each coinjected with $6 \mathrm{ng}$ of a template DNA and $0.5 \mu \mathrm{Ci}$ of $\left[\alpha^{-32} \mathrm{P}\right] \mathrm{GTP}$ and pools of 10 oocytes were harvested for RNA preparation after the indicated times of incubation at $18^{\circ} \mathrm{C}$. Total RNAs equivalent to two oocytes were analyzed by electrophoresis in $12 \%$ (30:0.8), $7 \mathrm{M}$ urea gels (Krol et al. 1985). For simplicity, only the regions of the gels containing the b1 and b2 U1 RNAs are shown. Autoradiograms were exposed for 20-24 hr without intensifying screens. $(B)$ Competition between $x U 1 b$ genes with chimeric promoter regions. The mutant $x U 1 b$ repeat templates contained genes with different (panels $1-3$ ) or identical (panels 4 and 5) 5' proximal promoter regions. Conditions of injections and gel analyses of total RNAs (isolated after 18-20 hr of incubation) were as in $A$. Preferential transcription of one gene over the other (panels 1-3) was observed independent of whether the $5^{\prime}$ distal promoter regions were different (panel 1 ) or identical (panels 2 and 3).

(data not shown) changes as a function of time of incubation. Therefore, the differential rates of accumulation of the $\mathrm{xU}$ lb RNAs presumably reflect different rates of transcription of the two $\mathrm{xU} 1 \mathrm{~b}$ genes, rather than differences in RNA stability or snRNP formation.

5 '-flanking sequences responsible for preferential accumulation of $\mathrm{x} U 1 \mathrm{~b} 2 \mathrm{RNA}$ To determine which region of the $\mathrm{xU} 1 \mathrm{~b}$ genes was responsible for the preferential accumulation of xU1b2 RNA, chimeric genes were injected in which the $5^{\prime}$-flanking sequences had been exchanged (Fig. 1B). When the entire 5 '-flanking regions of the two genes were exchanged, the ratio of the levels of $\mathrm{xU} 1 \mathrm{bl}$ to $\mathrm{xU} 1 \mathrm{~b} 2$ was reversed, so that the amount of $x U 1 b 1$ RNA was higher than that of $x U 1 b 2$ RNA (Fig. 2A, panel 2). No preferential accumulation was observed when the $5^{\prime}$-flanking regions of the two genes were identical (Fig. 2A, panels 3 and 4). These patterns of gene expression were independent of the relative positions of the chimeric $x U 1 b$ genes within the cloned repeats /data not shown), indicating that the 5 '-flanking regions of the two embryonic genes compete for one or more transcription factors that are limiting in injected oocytes.

Competition between genes was unaffected by switching the regions containing the enhancer (Fig. 2B). However, preferential transcription of an $\mathrm{xU}$ lb gene resulted when it contained the more proximal region of the $x U 1 b 2$ promoter (Fig. $2 B$, compare panels $1-3$ ). This conclusion was confirmed by the observation that $\mathrm{xU} 1 \mathrm{~b}$ genes with different enhancer regions but identical 5'proximal promoter regions were equally well transcribed (panels 4 and 5). We conclude that preferential transcription of the normal $x U 1 b 2$ gene results from the relative efficiency with which sequences close to its coding region bind a limiting transcription factors.

$x U 1 b$ genes compete only when injected in large amounts To obtain a more quantitative measure of the limiting factor, we examined the dose-response curve for transcription of the wild-type $\mathrm{xU} 1 \mathrm{~b}$ genes in injected oocytes. As illustrated in Figure 3 , the two genes were transcribed equally well when less than $1 \mathrm{ng}$ per oocyte of the wild-type repeat DNA was injected, mimicking the expression of the endogenous $x U 1 b$ genes during early oogenesis (Lund and Dahlberg, this issue). However, the xU1b2 gene was preferentially expressed after injection of more than $1 \mathrm{ng}$ of DNA per oocyte. Thus, the limiting factor is present in quantities sufficient to accommodate $1 \mathrm{ng}$ of template, a level well in excess of both the $10^{-5} \mathrm{ng}$ of endogenous $\mathrm{xU} 1 \mathrm{~b}$ repeat DNA in oocytes and the $10^{-2} \mathrm{ng}$ of repeat DNA present in midblastula embryos (cf. legend to Fig. 3B).

At nonsaturating concentrations of injected DNA, the levels of xUlb RNA transcripts per molecule of template were five- to tenfold higher than those of the heterologous human U1 RNA gene, hU1-1D (Murphy et al. 
A

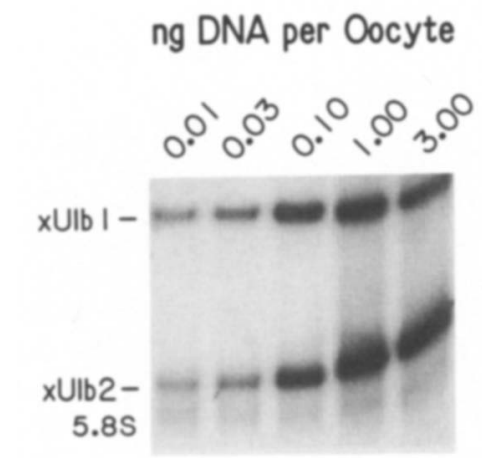

B

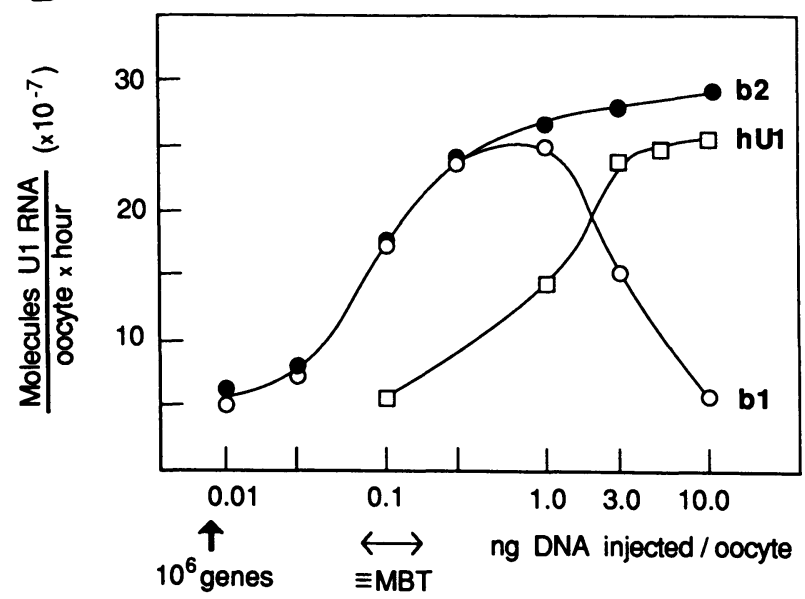

Figure 3. Efficiency of transcription of $X$. laevis embryonic U1 genes and a human U1 gene in injected oocytes. $(A)$ About $15-20$ oocytes were each coinjected with $0.5 \mu \mathrm{Ci}$ of $\left[\alpha^{-32} \mathrm{P}\right] \mathrm{GTP}$ and the indicated amounts of wild-type xUlb repeat DNA (1/1/1:2/2/2) (lanes 1-5) (or similar amounts of wild-type human U1 DNA, not shown). After $18 \mathrm{hr}$ of incubation, total RNAs were isolated from pooled oocytes and the RNAs equivalent to three oocytes were analyzed by electrophoresis in a nondenaturing $15 \%$ (19:1) polyacrylamide gel. Only the region of the gel containing the Ul RNAs is shown. $(B)$ The amounts of xU1bl (b1), xU1b2 (b2), and human U1 (hU1) RNAs synthesized in injected oocytes as a function of template DNA concentration. The number of U1 RNA molecules produced were estimated from the known specific activity of the injected precursor (see Materials and methods) and the measured radioactivity in the bands of U1 RNAs in the gel shown in $A$ and other comparable gels (not shown). The amounts of injected template DNA that correspond to $10^{6} \mathrm{xU} 1 \mathrm{~b}$ genes per oocyte (arrow) and the number of endogenous xUlb genes per embryo at the midblastula transition ( $\equiv \mathrm{MBT}$ ) are indicated. One oocyte has about $2 \times 10^{3}$ endogeneous copies of each $\mathrm{xU}$ lb gene.

1982; Skuzeski et al. 1984) (Fig. 3B). This difference probably reflects more efficient recognition by the frog oocyte transcription factors of the homologous $X$. laevis genes.

\section{Transcription in unfertilized eggs}

Transcription in unfertilized eggs resembles embryonic U1 RNA synthesis The relative transcription efficiencies of injected $\mathrm{xU} 1 \mathrm{~b}$ genes in stage VI oocytes (i.e., $x U 1 b 2 \geqq x U 1 b 1)$ do not reflect the transcription efficiencies of endogenous genes in early embryos (i.e., xU1b2 < xU1b1; Forbes et al. 1984; Lund and Dahlberg, this issue). To develop a transcription system that more closely resembles that of early embryos, we analyzed the expression of cloned $\mathrm{xU}$ lb genes upon injection into unfertilized eggs.

Pricking unfertilized eggs with a microinjection needle mimicks fertilization by activating the eggs to initiate DNA replication (Gurdon et al. 1969) and other events of the cell cycle (Hara et al. 1980). Although this leads to an apparent deterioration of the eggs within 5-10 hr after activation (Gurdon and Melton 1981), we found that expression of injected $\mathrm{xU}$ lb genes was detectable only after a lag period of at least $6 \mathrm{hr}$ (Fig. 4, compare lanes 3 and 5; see also Fig. 7, below; Bendig and Williams 1984).

When the wild-type $\mathrm{xU}$ lb gene repeat unit (Fig. 1A) was injected into eggs, both $\mathrm{xUlb}$ RNAs accumulated

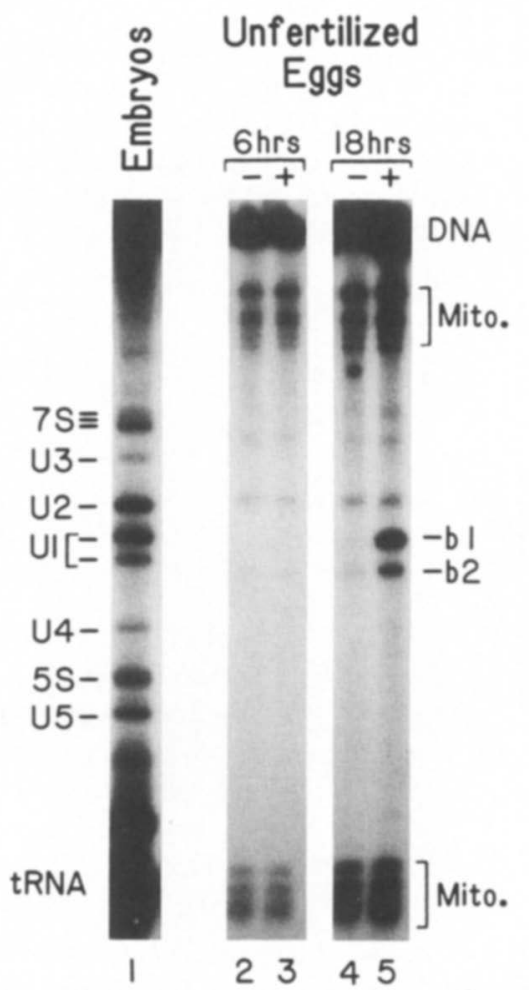

Figure 4. Transcription of embryonic Ul genes in injected unfertilized eggs. Comparison of xUlb RNA synthesis in injected unfertilized eggs and in gastrula embryos. Dejellied eggs were injected with or without $5 \mathrm{ng}$ of wild-type $\mathrm{xU}$ lb repeat DNA $(1 / 1 / 1: 2 / 2 / 2)$ DNA plus $\left[\alpha^{-32} \mathrm{P}\right] \mathrm{GTP}$ and incubated for 6 or $18 \mathrm{hr}$, as indicated. Total nucleic acids were isolated from pools of 10-12 eggs and analyzed as in Fig. 2, except that the autoradiogram was exposed for $30 \mathrm{hr}$ with intensifying screen. The products from the equivalent of four eggs injected with (lanes 3 and 5) or without (lanes 2 and 4) xUlb repeat DNA are shown. Total nucleic acids from gastrula embryos (lane 1) were obtained by pulse-labeling with ${ }^{32} \mathrm{PO}_{4}{ }^{3-}$ between $9-13 \mathrm{hr}$ after fertilization (cf. Lund and Dahlberg, this issue). 
(Fig. 4, lane 5) but the absolute levels of xUlbl RNA transcription was at least 50-fold less than in oocytes (cf. legend to Fig. 4). However, the ratio of xUlb to xUlb2 RNAs resembled that seen normally in early gastrula embryos (lane 1). In the absence of injected DNA, the transcripts from endogenous templates in activated eggs were principally mitochondrial RNAs (Fig. 4, lanes 2 and 4; cf. Gurdon and Melton 1981).

Sequences responsible for the preferential transcription of $x U 1 b 1$ genes When experiments with chimeric genes were performed in eggs, the differential accumulation again correlated with the type of 5 -flanking region of the gene (Fig. 5); furthermore, the effects were independent of the gene order within the plasmid DNA /data not shown), indicating competition for a limiting transcription factor. In contrast to the situation in oocytes, the xUlb1 5'-flanking region was the more efficient one in eggs (panels 1 and 2). Injection of genes with the same 5 '-flanking regions resulted in the production of equal amounts of xU1b1 and xU1b2 RNAs (panel 3). The less efficient $\mathrm{xU} 1 \mathrm{~b} 2$ promoter functioned well when injected alone (panel 4).

Sequences upstream of the enhancer region of the $\mathrm{xUlbl}$ gene are not responsible for its preferred transcription (panel 5). However, replacement of the enhancer regions of the $\mathrm{xU}$ lbl genes with that of the $\mathrm{xU} 1 \mathrm{~b} 2$ gene impaired the ability of the chimeric genes to

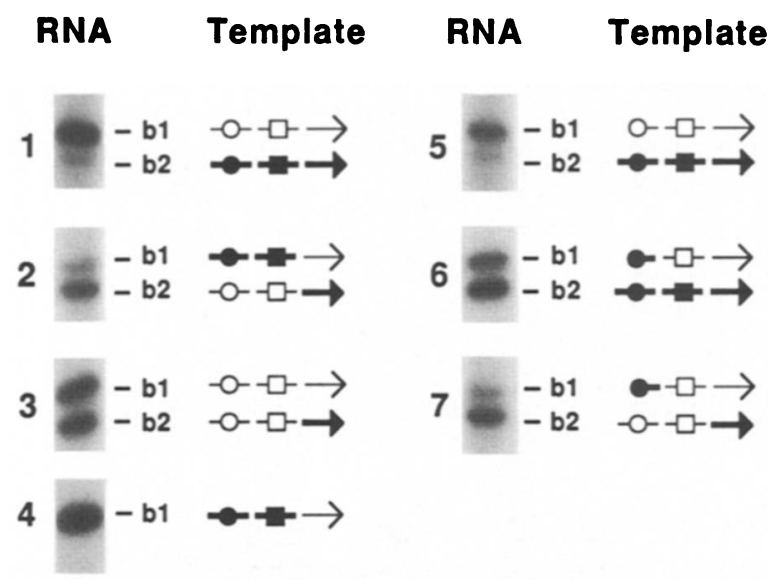

Figure 5. Transcriptional dominance of $x U 1 b 1$ genes with wild-type, truncated, or chimeric 5 '-flanking regions in unfertilized eggs. Groups of 10-12 unfertilized eggs were coinjected with $[\alpha-32$ P $]$ GTP and the templates indicated (at 5 ng DNA per egg) and incubated for 18-20 hr; total nucleic acids were analyzed as in Fig. 4, but only the regions of the gels containing bl and b2 U1 RNAs are shown. The templates were wild-type (panel 1) or mutant (panels 2 and 3) xU1b tandem repeats, each of which contained two genes with either different (panels 1 and 2) or identical 5'-flanking regions. The template in panel 4 contained only a single mutant $\mathrm{xU}$ lb gene. The other templates were mutant $\mathrm{xU} 1 \mathrm{~b}$ repeats containing genes with truncated $\left(1_{s} / 1 / 1\right)$ (panel 5$)$ or chimeric $(2 s / 1 / 1)$ promoter regions (panels 6 and 7) in combination with genes wild-type b2 (panels 5 and 6 ) or wild-type bl (panel 7) promoter regions. compete (compare panel 6 with 1 , and panel 7 with 3 ). We conclude that a transcription factor that interacts with sequences in the enhancer region probably is limiting in injected unfertilized eggs; thus, it differs from the factor that is limiting in oocytes.

Transcription control during in vitro maturation of oocytes We tested whether the difference in transcriptional dominance, which distinguishes expression of the injected $\mathrm{xU}$ lb genes in oocytes and eggs, could be reproduced by in vitro maturation of preinjected oocytes. Maturation of stage VI oocytes occurs within 10-15 hr of incubation with progesterone, as monitored by germinal vesicle breakdown (Gurdon 1967). In vitro-matured oocytes, like in vivo-matured eggs, are activated by pricking (Harland and Laskey 1980).

Initially (Fig. 6A), the injected $\mathrm{xU}$ 1b genes were transcribed very efficiently both in progesterone-treated and in control oocytes (i.e., more xU1b2 than xU1bl in lanes 1 and 2); presumably the RNAs in lane 1 were made before RNA synthesis ceased at germinal vesicle breakdown (LaMarca et al. 1975; Gelfand and Smith 1983). After maturation, (Fig. 6B), when the in vitro-matured oocytes were activated by the injection of the labeled GTP, the xUlb genes were again transcribed; however, at this time more $\mathrm{xU} 1 \mathrm{~b} 1 \mathrm{RNA}$ than $\mathrm{xU} 1 \mathrm{~b} 2$ RNA was made (lane 2), thereby reproducing the transcriptional dominance seen in in vivo-matured eggs and in early embryos (Fig. 4). As with unfertilized eggs, U1 RNA synthesis in in vitro-matured oocytes was detectable only after a lag period of several hours (Fig. 6B, lanes 1 and 2) and the efficiency of transcription was much lower than that of untreated control ooctyes (compare lanes 1 and 2 with lanes 3 and 4 and see legend to Fig. 6B). Also, the change in transcription of endogeneous DNAs was evident since chromosomal, but not mitochondrial, gene expression was suppressed.

Embryonic U1 RNA transcription in eggs depends on $D N A$ replication Activation of eggs by pricking stimulates the replication of both endogenous and injected DNAs (Gurdon et al. 1969; Harland and Laskey 1980). Since replication increases the amounts of both total DNA and specific templates, we investigated how DNA concentrations affected the transcription of injected $\mathrm{xU} 1 \mathrm{~b}$ genes in eggs.

The amounts of xUlb RNAs synthesized by $18 \mathrm{hr}$ were dose dependent over a range of injected template from 0.15 to $5 \mathrm{ng}$ DNA, but the ratio between the two RNAs remained unchanged (Fig. 7A). When $25 \mathrm{ng}$ of carrier pBR322 DNA was included to keep the total amount of injected DNA relatively constant, the accumulation of $\mathrm{xU} 1 \mathrm{~b}$ RNAs still increased in response to higher levels of template (lanes 4-6), indicating that the level of competent template was a limiting feature in determining $x U 1 b$ transcription in activated eggs.

The presence of carrier pBR322 DNA did significantly increase transcription of injected $\mathrm{xU}$ lb genes (Fig. 7A, lanes $1-31$; presumably, this was due to titration of nonspecific inhibitors of transcription that are present in eggs (Newport and Kirschner 1982b). In some eggs that 
Figure 6. Expression of injected embryonic genes during progesterone-induced maturation of stage VI oocytes. The synthesis of xUlb RNAs in oocytes injected with the wild-type $\mathrm{xU}$ lb repeat DNA (5 ng per oocyte) was examined during $(A)$ and after $(B)$ progesterone-induced maturation. $(A)$ Injected oocytes were labeled for $18 \mathrm{hr}$ in the presence (lane 1) or absence (lane 2) of progesterone $(1 \mu \mathrm{g} / \mathrm{ml}$ of incubation medium) as shown schematically. $(B)$ Preinjected matured oocytes (progesterone treated) (lanes 1 and 2) or control oocytes (lanes 3 and 4) were labeled for $4 \mathrm{hr}$ (lanes 1 and 3) or $20 \mathrm{hr}$ (lanes 2 and 4) as outlined in the diagram below. Total nucleic acids equivalent to three oocytes $(A$, lanes 1 and 2$)$, or four $(B$, lanes 1 and 2$)$ or $0.4(B$, lanes 3 and 4) oocytes, respectively, were analyzed as in Fig. 4. Autoradiograms were exposed for $20 \mathrm{hr}$ without screens $(A$, lanes 1 and 2$)$ or for $48 \mathrm{hr}$ with intensifying screens $(B$, lanes $1-4)$.

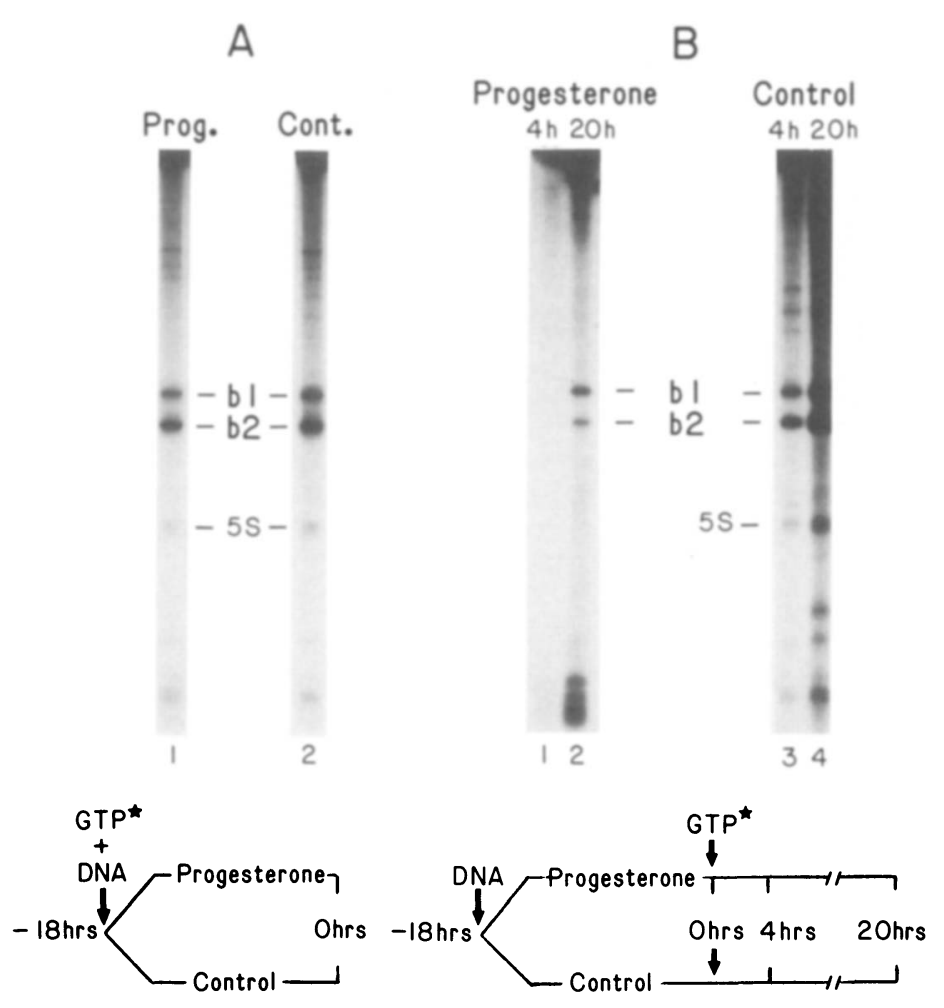

\section{Discussion}

We have demonstrated that the two $X$. laevis embryonic $\mathrm{U} 1$ genes $(\mathrm{xU} 1 \mathrm{~b} 1$ and $\mathrm{xU} 1 \mathrm{~b} 2)$ differ from each other in their abilities to form active transcription complexes after injection into either oocytes or unfertilized eggs. The limiting factor in injected stage VI oocytes interacts with sequences in the proximal promoter region of the $\mathrm{xU}$ lb genes, whereas the limiting factor in injected eggs recognizes more distal sequences, probably corresponding to the enhancer. Furthermore, in contrast to oocytes, transcription of injected $\mathrm{xU}$ lb genes in activated unfertilized eggs is dependent on DNA replication.

Transcription of exogenous $x U 1 b$ genes resembles that of endogenous genes The endogenous $\mathrm{xUlb}$ genes are transcriptionally quiescent in both stage VI oocytes and unfertilized eggs (Forbes et al. 1984). Nevertheless, exogenous $\mathrm{xU}$ lb genes are expressed and, when appropriate amounts of these genes are injected, the ratios of the levels of the two xU1b RNAs resemble those observed in vivo in related cell types. For example, equal amounts of $\mathrm{xU} 1 \mathrm{~b} 1$ and $\mathrm{xU} 1 \mathrm{~b} 2$ RNAs accumulate in stage VI oocytes that are injected with nonsaturating amounts of $\mathrm{xUlb}$ repeat DNA (i.e., $10-100 \mathrm{pg}$ ); correspondingly, the two embryonic U1 RNAs accumulate in a 1:1 ratio in previtellogenic oocytes (Lund and Dahlberg, this issue). Likewise the $\sim 5: 1$ ratio of accumulated $\mathrm{xU} 1 \mathrm{~b} 1$ and $\mathrm{xU} 1 \mathrm{~b} 2$ RNAs in injected eggs closely resembles the ratio of these RNAs synthesized normally at MBT (Forbes et al. 1984; Lund and Dahlberg, this issue).

Injection of relatively large amounts of the $\mathrm{xU} U \mathrm{~b}$ repeat DNA /with one copy each of the $\mathrm{xU} 1 \mathrm{~b} 1$ and $\mathrm{xU} 1 \mathrm{~b} 2$ 


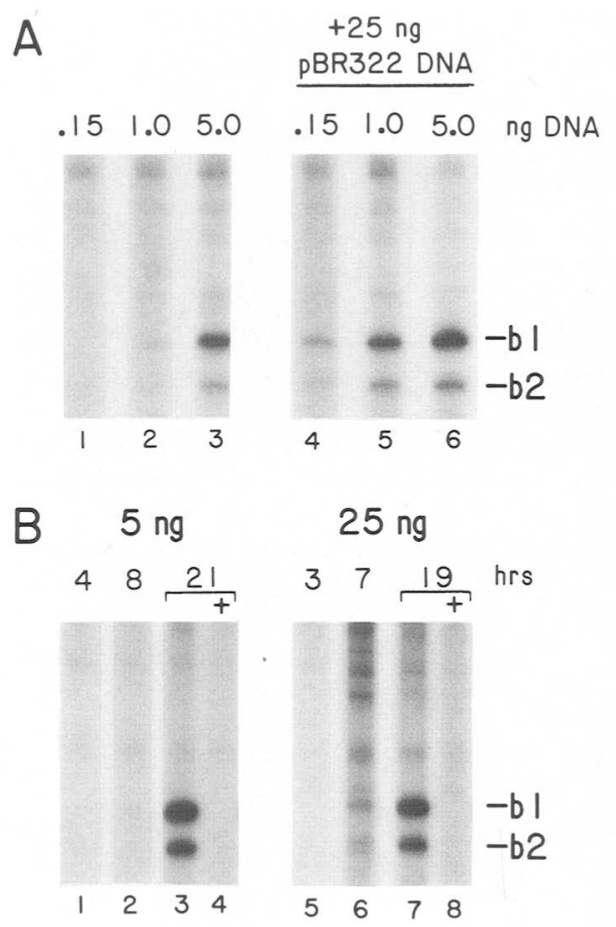

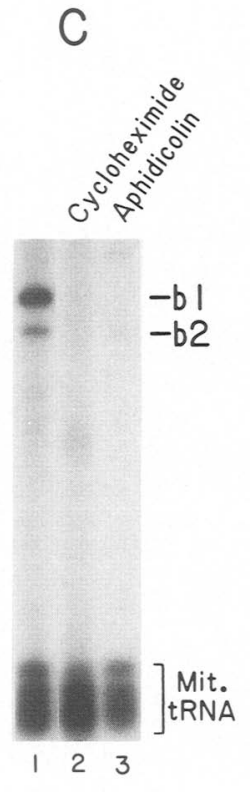

Figure 7. Expression of $\mathrm{xUlb}$ genes in unfertilized eggs depends on DNA concentration and replication. $(A)$ Analyses of xUlb RNAs from eggs injected with $1.5 \mu \mathrm{Ci}$ of $\left[\alpha^{-32} \mathrm{P}\right]$ GTP and $0.15 \mathrm{ng}$ (lanes 1 and 4), $1 \mathrm{ng}$ (lanes 2 and 5) or $5 \mathrm{ng}$ (lanes 3 and 6) of wild-type xUlb repeat DNA $(1 / 1 / 1: 2 / 2 / 2)$ alone (lanes $1-3$ ) or plus $25 \mathrm{ng}$ of pBR322 DNA (lanes 4-6). Incubation was for 18-20 hr and nucleic acids equivalent to three eggs were analyzed as in Figs. 4 and 5, except the autoradiograms were exposed for 10 days without intensifying screens. $(B)$ Analyses of $x U 1 b$ RNAs from eggs injected with $5 \mathrm{ng}$ (lanes $1-4$ ) or $25 \mathrm{ng}$ (lanes $5-8)$ of wild-type $x U 1 b$ repeat DNA (1/1/1:2/2/2) per egg. Injected eggs were incubated in the absence (lanes $1-3$ and $5-7$ ) or presence (lanes 4 and 8 ) of cycloheximide (100 $\mu \mathrm{g} / \mathrm{ml}$ of medium) for the indicated times. $(C)$ Analyses of xUlb RNAs from eggs injected with $5 \mathrm{ng}$ of wild-type xUlb repeat DNA (1/1/1:2/2/2) per egg and incubated for $18-20 \mathrm{hr}$ in the absence (lane 1) or presence of cycloheximide (100 $\mu \mathrm{g} / \mathrm{ml}$ of medium) (lane 2) or aphidicolin (20 $\mu \mathrm{g} / \mathrm{ml}$ of medium) (lane 3). genes) appears to saturate the transcriptional capacity of oocytes, as evidenced by the competition between $\mathrm{xU} 1 \mathrm{~b} 1$ and $\mathrm{xU} 1 \mathrm{~b} 2$ genes (Figs. 2 and 3). Under these conditions, the ratio of $\mathrm{xU}$ lb RNAs reflects not gene dosage (1:1), but the ability of the two embryonic genes to compete for a limiting transcription factor (cf. Westin et al. 1984; Murphy et al. 1987). Judging from the amount of injected DNA required for manifestation of this competition, we infer that the store in stage VI oocytes of the limiting transcription factor would be sufficient to accommodate all of the $\mathrm{xUlb}$ genes present in the embryo at the onset of endogenous snRNA transcription at MBT (Fig. 3). We recognize that there is no evidence that the concentration of this factor is the same in oocytes and at MBT.

Injected U1 RNA genes are very efficiently transcribed in oocytes The difference in template activities between the $X$. laevis $\mathrm{xU}$ lb genes and the human Ul gene in injected oocytes (Fig. 3) indicates that Ul transcription factors are, at least to some extent, species specific. Preliminary studies using human-frog chimeric U1 genes suggest that the proximal region of the 5 '-flanking sequences (position -1 to -200 ) is responsible for some of this difference in promoter strength (M. Schimerlik and E. Lund, unpubl.).

Irrespective of whether the snRNA genes are homologous (i.e., $X$. laevis) or heterologous (i.e., human or mouse), U1 and U2 RNA genes are by far the most active RNA polymerase II transcription units yet observed in injected oocytes or eggs (for a comparison with other genes, see review by Gurdon and Melton 1981; Bendig and Williams 1984). Under favorable conditions (i.e., in injected oocytes), the $X$. laevis embryonic U1 genes produce an average of 20-40 transcripts per gene per hour (Fig. 3), and are thus transcribed with an efficiency comparable to that of injected $X$. laevis 5S RNA and tRNA genes (Gurdon and Melton 1981); the actual rate of U1 RNA synthesis per gene is probably higher since not all of the injected genes would be expected to form active transcription complexes (Gargiulo et al. 1983). The fidelity of transcription, as measured by the percentage of U1 transcripts with correct $5^{\prime}$ and $3^{\prime}$ ends (Lund et al. 1984; Skuzeski et al. 1984), is also much higher than that of most other RNA polymerase II genes (Wickens et al. 1980; Bendig and Williams 1984).

Inactivation of U1 RNA transcription factors during oocyte maturation The striking differences between $\mathrm{U} 1$ gene transcription in oocytes and eggs, both in terms of the overall level of transcription and in the ratio of accumulated products, could result from any of several changes that occur upon maturation of oocytes. For example, some transcription factors may be inactivated or destroyed, as is the case with 5S rRNA-specific transcription factor (TFIIIA) (Shastry et al. 1984); selective inactivation, or loss, of a previously abundant factor that binds to the enhancer region would account for our observations. Alternatively, after nuclear breakdown the transcription factors and template would be in a different environment, and at different concentrations. This change in conditions might alter the efficiencies or specificities of factor-template interactions. We note that the same results were obtained both with templates 
that had been injected into the nucleus prior to in vitro maturation and with templates injected directly into eggs; thus, the effects that we are measuring are not simply a result of injecting DNA into a cell that has no nucleus.

It is unclear what is responsible for the lag in transcription of xUlb genes after activation of eggs. Although synthesis of additional amounts of template and of total DNA takes place during this period, other events related to the maintenance of the cell cycle clock are also occurring (for example, see Miake-Lye et al. 1983; Newport and Kirschner 1984). Thus, the lag may reflect the time necessary to activate or reactivate one or more transcription factors. In that regard it may well be analogous to the period prior to MBT, when embryos are transcriptionally inactive (Newport and Kirschner 1982a).

Coupling of transcription and DNA replication in injected eggs The stimulation of injected $\mathrm{xU} / \mathrm{b}$ genes in unfertilized eggs by nonspecific DNA is consistent with the notion that inhibitory factors (e.g., histones or nucleases) must be titrated out (or inactivated) before transcription from chromatin can occur (Newport and Kirschner 1982b). However, transcription also appears to require the act of DNA replication because regardless of the amount of carrier DNA injected, aphidicolin and cycloheximide block U1 RNA synthesis. This requirement is probably not specific to snRNA genes, since similar results have been reported for transcription of the $X$. laevis $\alpha$ - and $\beta$-globin genes and the herpes simplex virus thymidine kinase gene in injected unfertilized eggs (Bendig and Williams 1984).

The reasons for the dependence of RNA polymerase II transcription on DNA replication remains unclear. Replication may mediate necessary structural changes in the template DNA or chromatin, for example, to allow the exchange of the postulated general repressor of transcription (Newport and Kirschner 1982b) with gene-specific transcription factors. Alternatively, the effect of replication might be indirect if expression of injected RNA polymerase II genes were coupled to the formation of nuclear structures (Forbes et al. 1983a).

\section{Materials and methods}

Adult female Xenopus laevis were purchased from Xenopus I (Ann Arbor, Michigan). $\left[\alpha^{-32}\right.$ P]GTP was from Amersham Corporation. Restriction enzymes were from Promega Biotec or New England Biolabs. Cycloheximide and aphidicolin were from Sigma Corp.

\section{Injection of oocytes and eggs}

Preparation and injection of $X$. laevis oocytes were as previously described (Skuzeski et al. 1984; Krol et al. 1985), except that ooctyes were centrifuged for $10 \mathrm{~min}$ at $750 \mathrm{~g}$ and $5^{\circ} \mathrm{C}$, animal hemisphere up, to facilitate injection into the nuclei. Each oocyte received $0.5 \mu \mathrm{Ci}$ of $[\alpha-32 \mathrm{P}] \mathrm{GTP}$ and between 0.01 and 10 ng of supercoiled plasmid DNA /as indicated in the figure legends) in a total volume of $20 \mathrm{ml}$. Unless otherwise stated, incubation was at $18^{\circ} \mathrm{C}$ for $18-20 \mathrm{hr}$ in MBS- $\mathrm{H}$ [ $88 \mathrm{mM} \mathrm{NaCl}, 1$ $\mathrm{mm} \mathrm{KCl}, 2.4 \mathrm{~mm} \mathrm{NaHCO}{ }_{3}, 10 \mathrm{~mm}$ HEPES (pH 7.5), $0.8 \mathrm{~mm}$
$\mathrm{MgSO}_{4}, 0.3 \mathrm{mM} \mathrm{Ca}\left(\mathrm{NO}_{3}\right)_{2}, 0.4 \mathrm{mM} \mathrm{CaCl}, 10 \mu \mathrm{g} / \mathrm{ml}$ penicillin, $10 \mu \mathrm{g} / \mathrm{ml}$ streptomycin; Gurdon 1976]. Maturation of injected oocytes was induced by incubation with progesterone $(1 \mu \mathrm{g} / \mathrm{ml}$ of medium) for 15-18 hr, and matured oocytes were dissected individually to score for germinal vesicle breakdown (Gurdon 1967).

$X$. laevis eggs were obtained by injecting mature females with human chorionic gonadotropin (500-700 Units) 15-20 hr prior to egg collection. Eggs were laid in $\mathrm{MMR}(0.1 \mathrm{M} \mathrm{NaCl}, 2$ $\mathrm{mm} \mathrm{KCl}, 1 \mathrm{mM} \mathrm{MgSO}_{4}, 2 \mathrm{mM} \mathrm{CaCl} 2,5 \mathrm{~mm}$ HEPES, $0.1 \mathrm{~mm}$ EDTA (pH 7.8), $100 \mu \mathrm{g} / \mathrm{ml}$ penicillin, $50 \mu \mathrm{g} / \mathrm{ml}$ streptomycin; Newport and Kirschner 1982a) and immediately dejellied by treatment with $2-3 \%$ cysteine $(\mathrm{pH} 7.8)$ for about $5 \mathrm{~min}$ at room temperature. After rinsing several times with MMR, the eggs were transferred to injection medium, MMR with 5\% Ficoll (Newport and Kirschner 1982a). Each egg was injected with 1.0 $\mu \mathrm{Ci}$ of $[\alpha-32 \mathrm{P}] \mathrm{GTP}$ and varying amounts of template DNA (as indicated in the figure legends) in a total volume of $20 \mathrm{nl}$. Incubation was for $3-20 \mathrm{hr}$ (as indicated) at $18^{\circ} \mathrm{C}$. For inhibition of DNA replication, injected eggs were incubated in medium containing $100 \mu \mathrm{g} / \mathrm{ml}$ of cycloheximide or $20 \mu \mathrm{g} / \mathrm{ml}$ of aphidicolin.

\section{Analysis of RNA and DNA synthesis}

Total nucleic acids were extracted from individual or pooled oocytes or eggs and the accumulated transcripts were analyzed as described previously by electrophoresis in partially denaturing gels [containing $12 \%$ (30:0.8) polyacrylamide, $7 \mathrm{M}$ urea, and $1 \times$ TEB (85 mM Tris-borate, pH 8.3, 2 mM EDTA) (Krol et al. 1985)] or native gels [15\% (19:1), $1 / 2 \times$ TEB] (Forbes et al. 1984). Autoradiography of the wet gels was for $20-240 \mathrm{hr}$ without, or for 24-48 hr with, intensifying screens.

The number of U1 RNA molecules synthesized per oocyte (Fig. 3) was determined from the known specific activity of the $\left[\alpha-{ }^{32} \mathrm{P}\right]$ GTP precursor and the amount of radioactivity incorporated into newly synthesized UI RNAs. The radioactivity of gel bits containing the labeled UI RNAs was determined by Cerenkov counting and generally ranged from $0.2 \times 10^{3}$ to $2 \times 10^{3}$ dpm of U1 RNA synthesized per oocyte in $20 \mathrm{hr}$. The specific activity of the incorporated $\left.{ }^{32} \mathrm{P}\right] \mathrm{GTP}$ was $1.1 \times 10^{6} \mathrm{dpm}$ per 250 pmoles $(0.5 \mu \mathrm{Ci}$ injected at $\sim 1.25$ pmoles plus $\sim 250$ pmoles of endogenous GTP) or about $4 \times 10^{3} \mathrm{dpm}$ per pmole of GTP. Thus, $1000 \mathrm{dpm}$ of U1 RNA corresponds to 0.25 pmoles of GTP or, assuming 40 residues of GMP per U1 RNA, approximately 6 fmoles $\left(\sim 3.6 \times 10^{9}\right.$ molecules $)$ of U1 RNA. Similarly, the number of $\mathrm{Ul}$ genes injected was calculated to be $1.5 \times 10^{8}$ copies of each $\mathrm{xUlb}$ gene per $1 \mathrm{ng}$ of $\mathrm{xU}$ lb repeat DNA, which has a molecular mass of $4 \times 10^{6}$ daltons.

DNA synthesis in injected eggs (data not shown) was monitored by agarose gel electrophoresis of RNase-treated total nucleic acids.

\section{Construction of DNA templates}

The full-length $X$. laevis embryonic U1 repeat DNA containing both of the xUlb genes, pX1Ulb(1/1/1:2/2/2) (formerly pX1U1AB; Fig. $1 \mathrm{~A})$, and the two PstI subclones containing the separate xUlb genes, pXlUlb(1/1/1) and pXlUlb(2/2/2) [formerly pXIU1-A(P) and pX1U1-B(P), respectively] have been described previously (Krol et al. 1985). Chimeric xUlb genes, having the 5 '-flanking region of one gene and the coding region of the other gene, were constructed by cleavage of pXIUlb(1/1/1) and pX1U1b(2/2/2) DNAs with BclI (at position +27 of the U1 coding region) and BamHI (at position 375 of pBR322) and purification of the resulting two $B c l I-B a m H I$ fragments of each DNA by preparative agarose gel electrophoresis. The smaller 
fragment from one clone was then religated to the larger fragment from the other clone, and vice versa, to generate pX1U1b(1/1/2) and pX1U1b(2/2/1) (cf. Fig. 1B).

To generate $\mathrm{xU} / \mathrm{b}$ genes with chimeric promoter regions, the truncated xUlb genes pXLUlb $\left(1_{s} / 1 / 1\right)$ and pXIUlb $(2 s / 2 / 2)$ [formerly pX1U1-A(SP) and pX1U1-B(RP), respectively] were used. In both clones, the restriction enzyme cleavage site located immediately downstream of the enhancer region (i.e., the HindIII site at position -222 of the $\mathrm{xUlbl}$ gene and the MluI site at position -219 of the $\mathrm{xU} 1 \mathrm{~b} 2$ gene; cf. Fig. 1C) was converted to an XhoI site by insertion of an XhoI linker (CCTCGAGG) (Maniatis et al. 1982). The enhancer regions between xUlb genes were switched by exchange of $\mathrm{XhoI-BamHI}$ fragments, as outlined above for the exchange of entire 5 '-flanking regions.

Reconstruction of mutant $\mathrm{xU}$ lb gene repeat units, containing various combinations of wild-type and chimeric genes, was carried out according to the scheme devised by Krol et al. (1985) for the reconstruction of the full-length wild-type repeat unit from the two $\mathrm{xU}$ 1b subclones.

\section{Preparation of DNAs for injection}

All plasmids to be used as templates for transcription analyses were propagated in strain CAG 1574, whereas plasmids to be used for constructions involving cleavage with $B c$ lI were grown in strain GM $2163\left(\mathrm{dam}^{-}, d \mathrm{~cm}^{-}\right)$. Plasmid DNAs were prepared by the alkaline lysis method (Birnboim and Doly 1979), and supercoiled DNAs were collected after one round of $\mathrm{CsCl}-$ ethidium bromide density gradient centrifugation. Ethidium bromide was removed by extraction with isopropyl alcohol, and the DNAs were precipitated directly from the $\mathrm{CsCl}$ solutions by addition of 3 volumes of $70 \%$ ethanol. The recovered DNA was resuspended in $0.25 \mathrm{M} \mathrm{NaOAc}$ and reprecipitated with 2 volumes of $96 \%$ ethanol. The final pellet of DNA was dissolved in the appropriate volume of injection buffer containing $10 \mathrm{mM}$ Tris (pH 7.6), 1 mM EDTA.

\section{Acknowledgments}

We thank H. Neuman deVegvar for setting up our oocyte injection system, $M$. Wickens for useful discussions, and P. Tregloan for typing the manuscript. This work was supported by $\mathrm{Na}$ tional Institutes of Health grant GM 30220 and National Science Foundation grant PCM 83-09618 to J.E.D. and E.L.

\section{References}

Bendig, M.M. and J.G. Williams. 1984. Fidelity of transcription of Xenopus laevis globin genes injected in Xenopus laevis oocytes and nonfertilized eggs. Mol. Cell. Biol. 4: 21092119.

Birnboim, H.C. and J. Doly. 1979. A rapid alkaline extraction procedure for screening recombinant plasmid DNA. Nucleic Acids Res. 7: 1513-1523.

Ciliberto, G., G. Buckland, R. Cortese, and L. Philipson. 1985. Transcription signals in embryonic Xenopus laevis Ul genes. EMBO J. 4: 1537-1543.

Forbes, D.J., M.W. Kirschner, and J.W. Newport. 1983a. Spontaneous formation of nucleus-like structures around bacteriophage DNA microinjected into Xenopus laevis. Cell 34: 1323.

Forbes, D.J., T.B. Kornberg, and M.W. Kirschner. 1983b. Small nuclear RNA transcription and ribonucleoprotein assembly in early Xenopus development. J. Cell Biol. 97: 62-72.

Forbes, D.J., M.W. Kirschner, D. Caput, J.E. Dahlberg, and E. Lund. 1984. Differential expression of multiple U1 small nuclear RNAs in oocytes and embryos of Xenopus laevis. Cell 38: 681-689.

Fritz, A., R.F. Parisot, D. Newmeyer, and E.M. DeRobertis. 1984. Small nuclear U-RNPs in Xenopus laevis development: Uncoupled accumulation of the protein and RNA components. J. Mol. Biol. 178: 273-285.

Garguilo, G., W. Wasserman, and A. Worcel. 1983. Properties of the chromatin assembled on DNA injected into Xenopus oocytes and eggs. Cold Spring Harbor Symp. Quant. Biol. 43: $189-199$.

Gelfand, R.A. and L.D. Smith. 1983. RNA stabilization and continued RNA processing following nuclear dissolution in maturing Xenopus laevis oocytes. Dev. Biol. 99: 427-436.

Gurdon, J.B. 1967. On the origin and persistence of a cytoplasmic state inducing nuclear DNA synthesis in frogs' eggs. Proc. Natl. Acad. Sci. 58: 545-552.

1976. Injected nuclei in frog oocytes: Fate, enlargement and chromatin dispersal. I. Embryol. Exp. Morphol. 36: $523-540$.

Gurdon, J.B., M.L. Birnstiel, and V.A. Speight. 1969. The replication of purified DNA introduced into living cell cytoplasm. Biochim. Biophys. Acta 174: 614-628.

Gurdon, J.B. and D.A. Melton. 1981. Gene transfer in amphibian eggs and oocytes. Annu. Rev. Genet. 15: 189-218.

Hara, R., P. Tydeman, and M.W. Kirschner. 1980. A cytoplasmic clock with the same period as the division cycle in Xenopus eggs. Proc. Natl. Acad. Sci. 77: 462-466.

Harland, R.M. and R.A. Laskey. 1980. Regulated replication of DNA microinjected in eggs of X. laevis. Cell 21: 761-771.

Ikegami, S., T. Taguchi, M. Ohashi, M. Oguro, H. Nagano, and Y. Mano. 1978. Aphidicolin prevents mitotic cell division by interfering with the activity of DNA polymerase $\alpha$. Nature 275: 458-460.

Krol, A., E. Lund, and J.E. Dahlberg. 1985. The two embryonic Ul genes of Xenopus laevis have both common and genespecific transcription signals. EMBO I. 4: 1529-1535.

LaMarca, M.J., M.C. Strobel-Fidler, L. Dennis Smith, and K. Keem. 1975. Hormonal effects on RNA synthesis by stage 6 oocytes of Xenopus laevis. Dev. Biol. 47: 384-393.

Lund, E. and J.E. Dahlberg. 1987. Differential accumulation of U1 and U4 small nuclear RNAs during Xenopus development. Genes Dev. 1: 39-46.

Lund, E., J.E. Dahlberg, and D.J. Forbes. 1984. The two embryonic Ul snRNAs of Xenopus laevis are encoded by a major family of tandemly-repeated genes. Mol. Cell. Biol. 4: 25802586.

Maniatis, T., E.F. Fritsch, and J. Sambrook. 1982. Molecular cloning: A laboratory manual. Cold Spring Harbor Laboratory, Cold Spring Harbor, New York.

Miake-Lye, R., J.W. Newport, and M.W. Kirschner. 1983. Maturation promoting factor induces nuclear envelope breakdown in cycloheximide-arrested embryos of Xenopus laevis. J. Cell. Biol. 97: 81-91.

Murphy, J.T., R.R. Burgess, J.E. Dahlberg, and E. Lund. 1982. Transcription of a gene for human U1 small nuclear RNA. Cell 29: 265-274.

Murphy, J.T., J.M. Skuzeski, E. Lund, T.H. Steinberg, R.R. Burgess, and J.E. Dahlberg. 1987. Functional elements of the human U1 promoter III. Identification of five separate regions required for efficient transcription and template competition. J. Biol. Chem. 262: (in press).

Newport, J.W. and M.W. Kirschner. 1982a. A major developmental transition in early Xenopus embryos: I. Characterization and timing of cellular changes at the midblastula stage. Cell 30: 675-686.

- 1982b. A major developmental transition in early 
Lund et al.

Xenopus embryos: II. Control of the onset of transcription. Cell 30: 687-696.

1984. Regulation of cell cycle during early Xenopus development. Cell 37: 731-742.

Shastry, B.S., B.M. Honda, and R.G. Roeder. 1984. Altered levels of a $5 \mathrm{~S}$ gene-specific transcription factor (TFIIIA) during oogenesis and embryonic development of Xenopus laevis. J. Biol. Chem. 259: 11373-11382.

Skuzeski, J.M., E. Lund, J.T. Murphy, T.H. Steinberg, R.R. Burgess, and J.E. Dahlberg. 1984. Synthesis of human U1 RNA II. Identification of two regions of the promoter essential for transcription initiation at position +1 . J. Biol. Chem. 259: 8345-8352.

Wasserman, W.J. and L.D. Smith. 1978. The cyclic behavior of a cytoplasmic factor initiating meiotic maturation in Xenopus oocytes. J. Cell Biol. 78: R15-R22.

Westin, G., E. Lund, J.T. Murphy, U. Pettersson, and J.E. Dahlberg. 1984. Human U1 and U2 genes use similar transcription signals. $E M B O I$. 3: 3295-3301.

Wickens, M.P., S. Woo, B.W. O'Malley, and J.B. Gurdon. 1980. Expression of a chicken chromosomal ovalbumin gene injected into frog oocyte nuclei. Nature 285: 628-634.

Zeller, R., M.-T. Carri, I.W. Mattaj, and E.M. DeRobertis. 1984. Xenopus laevis Ul snRNA genes: Characterization of transcriptionally-active genes reveals major and minor repeated gene families. $E M B O J$. 3: 1075-1081. 


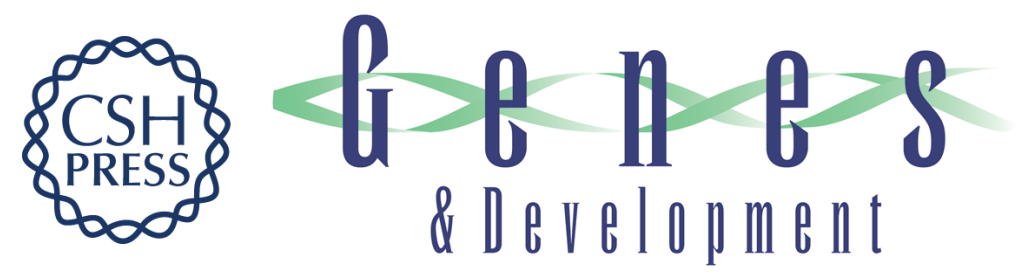

\section{The transcription of Xenopus laevis embryonic U1 snRNA genes changes when oocytes mature into eggs.}

E Lund, C J Bostock and J E Dahlberg

Genes Dev. 1987, 1:

Access the most recent version at doi:10.1101/gad.1.1.47

References This article cites 31 articles, 10 of which can be accessed free at: http://genesdev.cshlp.org/content/1/1/47.full.html\#ref-list-1

License

Email Alerting

Receive free email alerts when new articles cite this article - sign up in the box at the top Service right corner of the article or click here.

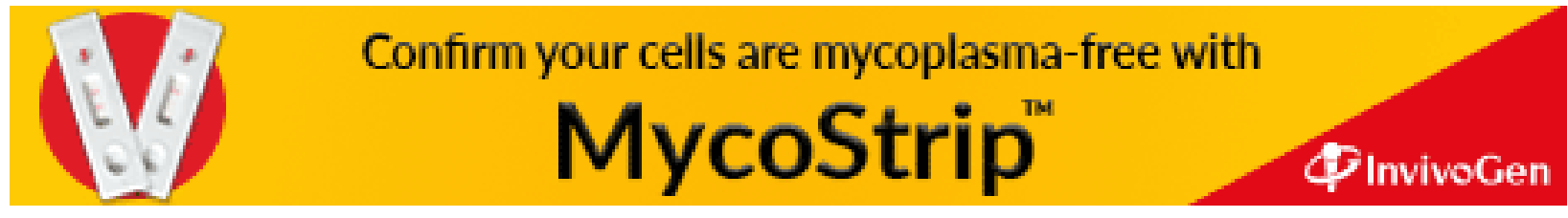

